\title{
PENGARUH KEPERCAYAAN DAN KEPUASAN KERJA TERHADAP INTENSI TURNOVER GURU SMKS CIKARANG UTARA
}

\author{
Reinelda Rani Rosalina ${ }^{1}$, Matin ${ }^{2}$, Kamaludin ${ }^{3}$ \\ Program Studi Manajemen Pendidikan, Universitas Negeri Jakarta ${ }^{123}$ \\ Email: rei.rosalina@gmail.com
}

\begin{abstract}
Abstrak
Penelitian ini bertujuan untuk mengetahui pengaruh dari (1) kepercayaan, (2) kepuasan kerja, (3) intensi turnover guru-guru yang bekerja di SMK Swasta di Kecamatan Cikarang Utara. Metode yang digunakan dalam penelitian ini adalah metode penelitian survey dengan pendekatan kuantitatif-kausal dengan menggunakan analisis jalur. Survey dilakukan sejak September sampai Desember 2017 dengan melibatkan 125 orang guru di suatu Kecamatan sebagai sampel yang ditentukan secara acak. Temuan dalam penelitan ini menunjukkan: pertama, terdapat pengaruh langsung negatif kepercayaan terhadap intensi turnover. Kedua, terdapat pengaruh langsung negatif kepuasan kerja terhadap intensi turnover. Ketiga, terhadap pengaruh langsung positif kepercayaan terhadap kepuasan kerja. Berdasarkan hasil penelitian, disarankan kepada Kepala Sekolah yang mana kedudukannya dalam sekolah juga sebagai menejer untuk dapat menjadi contoh nyata bagi guru-guru dalam menghargai dan mengapresiasi orang lain.
\end{abstract}

Kata Kunci : kepercayaan, kepuasan kerja, intensi turnover

\begin{abstract}
This study aims to know the effect of (1) trust, (2) job satisfaction, (3) turnover intention of teachers teaching at private Vocational High School (SMK) in North Cikarang District. Survey method with a quantitative-causal approach using path analyses is used to in this research. The survey was conducted from September to December 2017, involving 125 teachers in a District as randomly determined samples. The findings of this study show: first, there is a directly negative effect of trust on turnover intention. Second, there is a directly negative effect of job satisfaction on turn over intention. Third, there is a directly positive effect of trust on job satisfation. Based on the findings, it is suggested that the Principal whose position is also as a manager in the school be a good role model for the teachers in respecting and appreciating others.
\end{abstract}

Key Words : trust, job satisfaction, turnover intention

\section{PENDAHULUAN}

Pemerataan akses dan peningkatan mutu pendidikan secara alamiah akan mampu meningkatkan taraf hidup warga negara Indonesia karena mampu bersaing seiring dengan perkembangan zaman. Penyelenggaraan dan pengelolaan sekolah adalah salah satu wujud nyata dari pelayanan dalam bidang pendidikan oleh negara. Sekolah menempati posisi penting sebagai suatu institusi yang melaksanakan proses pendidikan pada tataran mikro. Kedudukan sekolah dinilai sangat penting dalam kehidupan masyarakat karena hal ini tidak terlepas dari fungsi sekolah sebagai lembaga pendidikan yang memiliki peran penting dan menentukan dalam perkembangan masyarakat. Sekolah sebagai suatu sistem memiliki komponenkomponen yang berkaitan satu sama lain serta berkontribusi pada pencapaian tujuan. Guru merupakan salah satu komponen yang memiliki peran penting dalam lembaga pendidikan. Oleh karena itu, Sumber Daya Manusia (SDM) yang ada tersebut harus dikelola dengan baik mulai dari tahap perekrutan dan seleksi hingga tahap penilaian kinerja. Di sisi lain, hal ini juga dinilai penting mengingat lembaga sekolah perlu mempertahankan SDM yang potensial agar tidak berdampak pada terjadinya perpindahan guru. Pindahnya 
guru yang potensial tentu saja dapat berdampak pada menurunnya kualitas proses pembelajaran di sekolah. Kejadian guru berpindah dari suatu sekolah ke sekolah lain menjadi fenomena yang banyak dijumpai sekarang ini. Keputusan guru untuk keluar dari sekolah tempat ia bekerja tentu saja dipengaruhi oleh banyak hal, di antaranya adalah karena faktor ekonomi yang dirasa kurang mampu mencukupi kebutuhan hidupnya dan keluarga, merasa kurang atau bahkan tidak dihargai dalam pekerjaannya, tidak merasa puas dalam pekerjaannya, rendahnya kepercayaan guru terhadap organisasi, karateristik tim yang beraneka ragam yang akhirnya membuat guru sulit untuk beradaptasi, budaya organisasi, dan faktor lainnya yang perlu diuji.

Kepercayaan merupakan hal besar bagi setiap orang untuk dapat berkontribusi secara efektif dan loyal terhadap organisasi. Rendahnya kepercayaan yang dirasakan oleh anggota terhadap organisasi akan mampu menjadi salah satu penyebab tingginya keinginan berpindah dari organisasi tersebut. Lebih dari itu, rendahnya kepercayaan anggota terhadap organisasi dapat memicu terjadinya konflik. Tidak adanya rasa saling percaya akan membuat orang saling menutup informasi dan ide-ide yang pada dasarnya dibutuhkan oleh setiap pihak dalam menjalankan pekerjaannya.

Konsep kepercayaan menurut Yukl bahwa, trust is established by being completely honest and open, keeping actions consistent with values, and showing trust in followers [1]. Kepercayaan muncul dari jujur dan terbuka yang sepenuhnya, tetap bertindak konsisten terhadap nilai, dan menunjukkan kepercayaan kepada para bawahan. Yukl memfokuskan konsep kepercayaan berdasarkan perspektif kepemimpinan, bahwa kepercayaan harus dimulai dari diri pimpinan untuk dicontoh oleh orang lain. Colquitt, et al. mengemukakan bahwa trust is defined as the willingness to be vulnerable to an authority based on positive expectations about the trusthy's actions and intentions [2]. Kepercayaan diartikan sebagai keinginan untuk mengikuti otoritas yang ada karena memiliki harapan positif terhadap pengaruh dan tujuan yang diberikan. Sedangkan Nelson and Quick mendefinisikan kepercayaan sebagai trust is the willingness to be vulnerable to the actions of another [3]. Kepercayaan adalah kemauan untuk memberikan kelonggaran terhadap tindakan orang lain. Pengertian lain mengenai kepercayaan yang dikemukakan George dan Jones yang mengatakan bahwa trust is an expression of confidence in another person or group of people that you will not be put at risk, harmed, or injured by their actions [4]. Kepercayaan adalah suatu perasaan yakin kepada seseorang atau kelompok yang mana dianggap tidak akan mencelakakan, merugikan atau melukai karena tindakan mereka yang dipercaya. Robbins dan Judge dalam bukunya juga mengatakan hal yang serupa bahwa trust is a psychological state that exists when you agree to make yourself vulnerable to another because you have positive expectations about how things are going to turn out [5]. Kepercayaan adalah keadaan psikologis yang muncul ketika anda setuju membuat diri anda rentan terhadap orang lain karena anda memiliki harapan positif tentang bagaimana keadaan akan berubah.

Selanjutnya, Robbins dan Coulter mengemukakan, trust is defined as the belief in the integrity, character, and ability of a leader [6]. Pernyataan ini dapat diartikan bahwa kepercayaan didefinisikan sebagai keyakinan pada integritas, karakter, dan kemampuan dari seorang pemimpin. Makna kepercayaan ini lebih spesifik pada profil pimpinan. Pengikut yang percaya kepada pimpinan bersedia 
menguasakan kepentingannya pada pimpinan, karena mereka yakin bahwa hak dan kepentingan mereka tidak akan disalahgunakan. Kondisi ini dapat menyebabkan pegawai cenderung tidak nyaman dalam bekerja di dalam organisasi tersebut, sehingga dengan sendirinya dapat menurunkan kepuasan kerja pegawai. Kepuasan kerja merupakan salah satu faktor yang juga berpengaruh terhadap intensi turnover pada pegawai. Rendahnya kepuasan kerja yang dirasakan oleh para anggota dapat menurunkan semangat untuk terus meningkatkan kinerjanya, sekaligus membuat tingkat turnover menjadi semakin meninggi.

Menurut informasi yang didapat, guru swasta mencari perbaikan nasib dengan cara berpindah-pindah dalam kehidupan mengajarnya di lembaga swasta. Sebagaimana yang dilansir oleh media elektronik sebagai berikut: "Ngenes jadi guru swasta nasibnya tetap awet yaitu awet dalam keterbatasan perekonomian. Guru-guru swasta yang berkualitas karena keadaannya seperti itu maka pontang panting mencari tempat yang lebih baik dan akhirnya pindah sana dan pindah sini atau malah keluar dari guru karena dirasa menjadi guru tidak bisa mencukupi hajat hidup. Mengingat seringnya guru swasta yang mencari perbaikan nasib, dengan pindah-pindah dalam mengajarnya lembaga swasta memikirkan bukan bagaimana supaya kesejahteraan gurunya meningkat dan bagaimana supaya gurunya betah di lembaga tersebut tetapi malah yang dipikirkan adalah bagaimana cara menjerat guru supaya tidak gampang pindah dengan jeratan-jeratan. Ada lagi lembaga swasta yang dalam rangka menjerat guru supaya awet dalam mengajarnya di lembaga tersebut memberlakukan penahanan terhadap ijazah asli guru sebagai jaminan supaya tidak gampang kabur dan apabila keluar alias tidak mengajar di situ lagi dalam waktu tertentu jangankan dapat pesangon eh malah didenda jutaan rupiah" [7].

Masalah kepuasan kerja yang berdampak pada intense turnover ini diperkuat dengan munculnya sebuah tulisan dari detik.com yang menyebutkan: "Gaji GTT di sejumlah daerah yang belum menerapkan UMK hanya sekitarRp 500 ribu bahkan Rp 250 ribu per bulan. Jika dibandingkan dengan upah buruh pabrik sangat jauh rentangnya. Buruh pabrik yang kebanyakan lulusan SMP bahkan SD, digaji sesuai standar UMK, namun guru yang lulusan sarjana hanya digaji di bawah UMK" [8].

Nyatanya untuk merekrut guru di wilayah Cikarang yang notabene merupakan kota industry bukanlah perkara mudah. Tentu saja lebih banyak para lulusan muda yang menggantungkan nasibnya sebagai pegawai kantoran atau karyawan pabrik. Kalaupun ada yang menjadi guru, tentu mereka akan lebih memilih untuk menjadi guru di Ibu Kota yang managajinya lebih menjamin dibandingkan harus mengajar di sekolah swasta di daerah Cikarang.

Menurut Schermerhorn, Hunt, dan Osborn, job satisfaction is the degree to which an individual feels positively or negatively about his job [9]. Kepuasan kerja adalah sejauh mana seorang individu merasa positif atau negatif tentang pekerjaannya. George dan Jones juga menyebutkan, job satisfaction is the collection of feelings and beliefs that people have about their current jobs [4]. Kepuasan kerja adalah kumpulan perasaan dan rasa percaya yang dimiliki seseorang mengenai pekerjaannya saat ini. Hal ini juga sesuai dengan pendapat Robbins dan Coulter yang menjelaskan bahwa, a person with a high level of job satisfaction has a positive attitude toward his her job, while a person who is dissatisfaction has negative attitude [10]. Seseorang yang mempunyai kepuasan kerja yang tinggi akan melakukan tindakan 
positif terhadap pekerjaaanya, sebaliknya orang yang tidak puas akan menunjukkan tindakan negatif.

Gibson, Ivancevich dan Donnely mengatakan, job satisfaction is an individual's expression of personal wellbeing associated with doing the job assigned [11]. Kepuasan kerja adalah ungkapan perasaan seseorang tentang kesejahteraan personal dalam kaitannya dengan pekerjaan yang dibebankan kepadanya. Menurut Luthans, job satisfaction is a pleasurable or positive emotional state resulting from the appraisal of one [12]. Kepuasan kerja adalah suatu keadaan emosi yang meyenangkan atau positif sebagai akibat dari pengalaman atau penilaian seseorang.

Menurut Kreitner dan Kinicki terdapat lima hal yang berkaitan kepuasan kerja seseorang yaitu: “....with the following job dimensions: work, pay, promotions, coworkers, and supervision" yang berarti dimensi pekerjaan yang berkaitan dengan kepuasan kerja antara lain adalah, pekerjaan itu sendiri, gaji, promosi, rekan kerja, dan pengawasan [13].

Mengacu pada definisi konseptual di atas, dapat dilihat bahwa kepercayaan dan kepuasan kerja dapat menjadi faktor penting bagi seseorang untuk menentukan apakah ia akan tetap tinggal atau keluar dari suatu organisasi. Grobler dan Wärnich dalam bukunya menyebutkan turnover intention is the organization's employees plan to leave their jobs or to fire their employees [14]. Intensi turnover adalah karyawan dalam suatu organisasi berencana untuk meninggalkan pekerjaannya atau untuk memecat karyawan mereka.

Menurut Alan M. Saks turnover intention is defined as an employee's voluntary intention to leave or quit an organizarion
[15]. Intensi turnover didefinisikan sebagai niat sukarela karyawan untuk pergi atau keluar dari organisasi. AlBattat dan Som juga memaparkan bahwa turnover intention is the crucial stage before the actual turnover occurs. Unmet expectations can lead to turnover intentions which force the employee to ultimately quit [16]. Intensi turnover adalah tahap yang paling krusial sebelum turnover yang sesungguhnya terjadi. Harapan-harapan yang tidak tercapai dapat memicu terjadinya intensi turnover yang akhirnya mendesak karyawan untuk akhirnya mengundurkan diri.

Turnover ini perlu disikapi sebagai suatu fenomena dan perilaku penting dalam kehidupan serta keberlangsungan organisasi. Dalam kesempatan wawancara dengan Kepala SMKS Sentra Medika, Nuphanudin, menyebutkan bahwa dari total 23 guru yang ada, setidaknya dalam setahun minimal 1 sampai 2 orang yang keluar. Hal serupa juga diungkapkan oleh Abdul Mujib, yang kini menjabat sebagai Kepala SMKS Laboratorium Global. Beliau juga sebenarnya mengeluhkan bila setiap tahunnya ada saja guru yang keluar. Masalah turnover memang tidak bisa dihindari. Tinggal bagaimana sekolah menyikapinya dan mencari jalan keluar untuk meminimalisir tingkat turnover pada guru-guru tersebut.

\section{METODE}

Penelitian ini bertujuan untuk menguji pengaruh langsung; (1) kepercayaan terhadap intensi turnover, (2) kepuasan kerja terhadap intensi turnover, dan (3) kepercayaan terhadap kepuasan kerja. Penelitian ini menggunakan metode survey dengan pendekatan teknik analisis jalur. Penelitian dilaksanakan di SMK Swasta di Kecamatan Cikarang Utara. Populasi terjangkau penelitian ini sejumlah 182 guru. Sampel penelitian sebanyak 125 orang. Analisa data untuk pengujian 
hipotesis dilakukan dengan menggunakan teknik analisis jalur, yaitu teknik yang diterapkan untuk menjelaskan pengaruh antara variabelvariabel penelitian. Sebelum dilaksanakan analisis jalur, uji signifikan regresi dan uji linearitas regresi sebagai prasyarat uji statistik dilakukan pengujian penormalan data dari masing-masing variabel penelitian dengan Uji-Liliefors, Statistik inferensial digunakan untuk menguji hipotesis tentang pengaruh antar variabel dengan menggunakan teknik analisis jalur.

\section{HASIL DAN PEMBAHASAN \\ Pengaruh Kepecayaan terhadap Intensi Turnover}

Dari hasil pengujian hipotesis pertama dapat disimpulkan bahwa terdapat pengaruh langsung negatif kepecayaan terhadap intensi turnover dengan nilai koefisien korelasi sebesar $-0,224$ dan nilai koefisien jalur sebesar -0,295. Ini memberikan makna kepercayaan berpengaruh langsung negatif terhadap intensi turnover.

Tabel 1. Koefisien Jalur Pengaruh $\mathbf{X}_{1}$ terhadap $\mathrm{X}_{3}$

\begin{tabular}{|c|c|c|c|c|}
\hline \multirow{2}{*}{$\begin{array}{l}\text { Pengaruh } \\
\text { langsung }\end{array}$} & \multirow{2}{*}{$\begin{array}{c}\text { Koefisien } \\
\text { Jalur }\end{array}$} & \multirow[b]{2}{*}{$\mathbf{t}_{\text {hitung }}$} & \multicolumn{2}{|c|}{$\mathbf{t}_{\text {tabel }}$} \\
\hline & & & $\begin{array}{c}\alpha= \\
0,05\end{array}$ & $\begin{array}{c}\alpha= \\
0,01\end{array}$ \\
\hline $\begin{array}{c}\mathrm{X}_{1} \text { terhadap } \\
\mathrm{X}_{3} \\
\end{array}$ & $-0,295$ & $\begin{array}{c}-3,43 \\
* * \\
\end{array}$ & 1,98 & $\begin{array}{c}- \\
2,62 \\
\end{array}$ \\
\hline
\end{tabular}

Hasil penelitian ini senada dengan pendapat beberapa ahli di antaranya adalah Ozturk, Hancer, dan Wang, interpersonal trust was identified as the main antecedent of turnover intention at the team level [17]. Kepercayaan interpersonal diidentifikasi sebagai pemicu utama dari intensi turnover pada tingkat kelompok. Lebih dalam lagi mereka menjelaskan bahwa, the higher the interpersonal trust, the greater the employee benefits and the fewer the costs for employee turnover [17]. Semakin tinggi kepercayaan antar karyawan, semakin besar pula keuntungan yang didapat dari karyawan tersebut sehingga semakin rendah pula biaya yang harus dikeluarkan untuk turnover karyawan.

Costigan, et al. juga menyampaikan hal yang serupa, low trust can result in employees having difficulty in cooperating and accelerate the speed of reductions in mental resources. Thus, high interpersonal trust can ensure that an employee is willing to stay while low trust will generate the employee's intention to leave. In sum, the higher the interpersonal trust in a team, the lower the employees' turnover intention [18]. Kepercayaan yang rendah dapat membuat karyawan kesulitan dalam mengoperasikan dan meningkatkan kecepatan reduksi sumber daya mental. Maka, bila kepercayaan antar karyawan tinggi dapat dipastikan bahwa seorang karyawan akan bersedia untuk tinggal sementara bila tingkat kepercayaan rendah akan menimbulkan niat dalam diri karyawan untuk pindah. Alhasil, semakin tinggi kepercayaan antar karyawan dalam sebuah kelompok, semakin rendah pula tingkat intensi turnovernya. Hal yang tidak jauh berbeda juga disampaikan oleh Karabay yang menyebutkan bahwa, one of the factors that affect the turnover intention is the trust towards organization [19]. Salah satu faktor yang mempengaruhi intensi turnover adalah kepercayaan terhadap organisasi. Dalam hal ini berarti kepercayaan memainkan peranan yang sangat penting dalam kaitannya dengan intensi turnover, baik itu kepercayaan antar karyawan maupun kepercayaan terhadap atasan.

Berdasarkan uraian di atas, maka jelaslah bahwa kepercayaan berpengaruh langsung negatif terhadap intensi turnover, jika kepercayaan ditingkatkan maka akan mengakibatkan menurunnya intensi turnover. 


\section{Pengaruh Kepuasan Kerja terhadap Intensi Turnover}

Dari hasil pengujian hipotesis kedua dapat disimpukan bahwa terdapat pengaruh langsung negatif kepuasan kerja terhadap intensi turnover dengan nilai koefisien korelasi sebesar -0,290 dan nilai koefisien jalur sebesar -0,345. Ini memberikan makna kepuasan kerja berpengaruh langsung negatif terhadap intensi turnover.

\section{Tabel 2. Koefisien Jalur Pengaruh $X_{2}$ terhadap $\mathrm{X}_{3}$

\begin{tabular}{ccccc}
\hline \multirow{2}{*}{$\begin{array}{c}\text { Pengaruh } \\
\text { langsung }\end{array}$} & $\begin{array}{c}\text { Koefisien } \\
\text { Jalur }\end{array}$ & $\mathbf{t}_{\text {hitung }}$ & \multicolumn{2}{c}{$\mathbf{t}_{\text {tabel }}$} \\
\cline { 4 - 5 } & & & $\begin{array}{c}\boldsymbol{\alpha}= \\
\mathbf{0 , 0 5}\end{array}$ & $\begin{array}{c}\boldsymbol{\alpha}= \\
\mathbf{0 , 0 1}\end{array}$ \\
\hline $\begin{array}{c}\mathrm{X}_{2} \text { terhadap } \\
\mathrm{X}_{3}\end{array}$ & $-0,345$ & $\begin{array}{c}-4,07 \\
* *\end{array}$ & $-1,98$ & $-2,62$ \\
\hline$* *$ Koefisien jalur sangat signifikan & $-4,07<-2,62$ pada $\alpha=0,01)$
\end{tabular}

Hasil penelitian ini senada dengan pendapat beberapa ahli di antaranya adalah pendapat dari Schermerhorn, Hunt, dan Osborn yang berpendapat mengenai hal ini. Mereka menyebutkan, satisfied workers are more likely to remain with their present employers, while dissatisfied workers are more likely to quit or at least be on the lookout for other jobs [9]. Pegawai yang puas akan lebih memilih untuk mempertahankan pekerjaannya saat ini, sementara pegawai yang tidak puas akan lebih memilih untuk keluar dari pekerjaannya atau setidaknya mulai mencari pekerjaan lain. Sependapat dengan George dan Jones juga menyebutkan bahwa employees very satisfied with their jobs may never even think about quitting; for those who are dissatisfied, it is the dissatisfaction that starts them thinking about quitting [4]. Karyawan yang sangat puas dengan pekerjaan mereka mungkin tidak pernah berpikir untuk berhenti; namun bagi mereka yang tidak puas, ketidakpuasan itulah yang membuat mereka mulai berpikir untuk keluar dari pekerjaannya. Hal ini tidak jauh berbeda dengan apa yang dikemukakan oleh Sara et al., yakni promotion opportunities, pay level and rewards have negative and significant effect on turnover intentions. It is proven that the more satisfied employees were with their promotion opportunities, pay level and rewards, the less likely they are intention to leave their current employer [20]. Peluang promosi, tingkat gaji dan penghargaan berpengaruh negatif dan signifikan terhadap niat berpindah. Terbukti bahwa semakin banyak karyawan yang puas dengan peluang promosi mereka, tingkat gaji dan penghargaan, semakin kecil kemungkinan mereka untuk meninggalkan perusahaan mereka saat ini. Lebih lanjut, Sara et al. juga menegaskan bahwa job satisfaction has a negative impact on turnover intention. High job satisfaction is associated with low turnover intention and low job satisfaction leads toward high turnover intention. It is the best indicator of employ intention to perform [20]. Kepuasan kerja memiliki dampak negatif terhadap intensi turnover. Kepuasan kerja yang tinggi dikaitkan dengan rendahnya intensi turnover dan kepuasan kerja yang rendah mengarah pada intensi turnover yang tinggi. Ini adalah indikator terbaik dari niat kerja pegawai.

Berdasarkan uraian di atas, maka jelaslah bahwa kepuasan kerja berpengaruh langsung negatif terhadap intensi turnover, jika kepuasan ditingkatkan maka akan mengakibatkan menurunnya intensi turnover.

\section{Pengaruh Kepercayaan terhadap Kepuasan Kerja}

Dari hasil pengujian hipotesis ketiga dapat disimpulkan bahwa terdapat pengaruh langsung positif kepercayaan terhadap kepuasan kerja dengan nilai koefisien korelasi sebesar 0,244 dan nilai koefisien jalur sebesar 0,244. Ini memberikan makna kepercayaan berpengaruh langsung positif terhadap kepuasan kerja. 
Tabel 3. Koefisien Jalur Pengaruh $X_{1}$ terhadap $\mathrm{X}_{2}$

\begin{tabular}{ccccc}
\hline \multirow{2}{*}{$\begin{array}{c}\text { Pengaruh } \\
\text { langsung }\end{array}$} & $\begin{array}{c}\text { Koefisien } \\
\text { Jalur }\end{array}$ & $\mathbf{t}_{\text {hitung }}$ & \multicolumn{2}{c}{$\mathbf{t}_{\text {tabel }}$} \\
\cline { 4 - 5 } & & $\begin{array}{c}\boldsymbol{\alpha}= \\
\mathbf{0 , 0 5}\end{array}$ & $\begin{array}{c}\boldsymbol{\alpha}= \\
\mathbf{0 , 0 1}\end{array}$ \\
\hline $\begin{array}{c}\mathrm{X}_{1} \text { terhadap } \\
\mathrm{X}_{2}\end{array}$ & 0,244 & $\begin{array}{c}2,79 \\
* *\end{array}$ & 1,98 & 2,62 \\
\hline$* *$ Koefisien jalur sangat signifikan $(2,79>2,62$ pada $\alpha=0,01)$
\end{tabular}

Hasil penelitian ini senada dengan pendapat beberapa ahli di antaranya adalah Robbins dan Coulter, mereka mengungkapkan bahwa, research has shown that trust in leadership is significantly related to positive job outcomes, including job performance, job satisfaction, and organizational commitment [6]. Penelitian telah menunjukkan bahwa kepercayaan dalam kepemimpinan secara signifikan berhubungan dengan hasil pekerjaan yang positif, termasuk prestasi kerja, kepuasan kerja, dan komitmen organisasi. Robbins dan Judge, juga berpendapat sebagai berikut leaders who break psychological constract with workers, demonstrating they aren't trustworthy, will find employees are less satisfied and less commited, have higher intentions to turnover, engage in less citizenship behavior, and have lower task performance [5]. Pemimpin yang melanggar konstruksi psikologis dengan pekerja, menunjukkan bahwa mereka tidak dapat dipercaya, sehingga akan mendapati bahwa karyawan kurang puas dan kurang berkomitmen, memiliki niat lebih tinggi untuk melakukan turnover, terlibat dalam perilaku kewarganegaraan yang kurang baik, dan memiliki kinerja yang lebih rendah. Hal senada juga di sampaikan oleh Janasz yang dikemukan sebagai berikut organizations with low or no trust are susceptible to a range of negative employee responses, including high turnover, reduced job satisfaction, less cooperation, and increased absenteeism [21]. Organisasi dengan tingkat kepercayaan rendah atau bahkan tidak ada, rentan terhadap sejumlah tanggapan negatif dari karyawan, termasuk tingginya jumlah turnover, menurunkan kepuasan kerja, berkurangnya kerja sama, dan juga absensi yang meningkat.

Berdasarkan uraian di atas, maka jelaslah bahwa kepercayaan berpengaruh langsung positif terhadap kepuasan kerja, jika kepercayaan ditingkatkan maka akan mengakibatkan meningkatnya kepuasan kerja.

Ringkasan model analisis jalur dapat terlihat pada gambar 1 sebagai berikut:

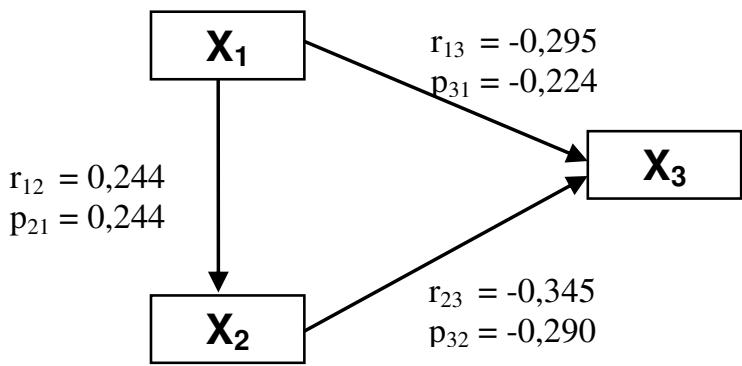

\section{Gambar 1. Model Empiris Antar Variabel}

\section{SIMPULAN}

Berdasarkan hasil penelitian, maka diperoleh kesimpulan sebagai berikut 1) Kepercayaan berpengaruh langsung negatif terhadap intense turnover. Artinya, rendahnya tingkat kepercayaan guru mengakibatkan peningkatan intense turnover guru SMK Swasta di Kecamatan Cikarang Utara. 2) Kepuasan Kerja berpengaruh langsung negatif terhadap intense turnover. Artinya, rendahnya kepuasan kerja yang dirasakan oleh guru mengakibatkan peningkatan intense turnover guru SMK Swasta di Kecamatan Cikarang Utara. 3) Kepercayaan berpengaruh langsung positif terhadap kepuasan kerja. Artinya, tingginya tingkat kepercayaan guru mengakibatkan peningkatan terhadap kepuasan kerja yang dirasakan oleh guru SMK Swasta di Kecamatan Cikarang Utara. 


\section{DAFTAR PUSTAKA}

[1] G. A. Yukl. Leadership in Organizations. New Jersey: Prentice Hall, 2010.

[2] J. A. Colquitt, Jeffery A. Lepine and Michael J. Wesson. Organizational Behavior: Improving Performance and Commitment in the Workplace. New York: McGraw-Hill/Irwin, 2009.

[3] D. L. Nelson and James Campbell Quick. Organizational Behavior. London: SAGE Publications Ltd., 2006.

[4] J. M. George and Gareth R. Jones. Understanding and Managing Organizational Behavior $6^{\text {th }}$ edition. Upper Saddle River: Prentice Hall, 2012.

[5] S. P. Robbins and Timothy A. Judge. Organizational Behavior, $15^{\text {th }}$ edition. New Jersey: Pearson Education, Inc., 2013.

[6] S. P. Robbins and Mary Coulter.Management, $11^{\text {th }}$ edition. New Jersey: Pearson Prentice Hall, 2012

[7] http://www.kompasiana.com/jokowi narto/ngenes-jadi-guru-swastakeluar-malah-didenda [Diakses 22 Mei 2017]

[8] https://news.detik.com/kolom/d3528958/gaji-humanis-guru[Diakses 26 Juni 2017]

[9] J. R. Schermerhorn, James G. Hunt and Richard N. Osborn. Organizational Behavior, $11^{\text {th }}$ edition. New York: John Wiley \& Son, Inc., 2010.

[10] S. P. Robbins and Mary Coulter.Management, Pearson International Edition. New Jersey: Pearson Prentice Hall, 2007.

[11] J. L. Gibson, John M. Ivancevich, and James H. Donnelly, Jr. Organizations: Behavior, Structure, Process. New York: McGraw-Hill, 2012.
[12] F. Luthans. Organizational Behavior $12^{\text {th }}$ edition. New York: Mc GrawHill, 2011.

[13] A. Kinicki and Robert Kreitner. Organizational Behavior, Key Concept, Skill and Best Practices. New York: McGraw-Hill, 2008.

[14] P. Grobler and Surette Wärnich. Human Resource Management in South Africa $3^{\text {rd }}$ edition. London: Thomson Learning, 2005.

[15] A. M. Saks. "Antecedents and Consequences of Employee Engagement". Journal of Managerial Psychology, 7: 600-619, 2006.

[16] A. R. S. AlBattat and Mat Som. "Employee Dissatisfaction and Turnover Crises in the Malaysian Hospitality Industry". International Journal of Business \& Management, vol. 5, pp. 62-71, 2013.

[17] A. B. Ozturk, Murat Hancer, and Yao-Chin Wang. Cross Level Perspective of Hospitaly Employee Turnover. Orlando: Cognizant Comm, Corp, 2014.

[18] Costigan, R. D. et al., "A FourCountry Study of the Relationship of Effect-Based Trust to Turnover Intention". Journal of Applied Social Psychology, vol. 5, pp. 1123-1124, 2012.

[19] Karabay, Melisa Erdilek. "A Research on Insurance Sector". International Journal of Engineering Education, vol. 5, pp. 28-46, 2016.

[20] D. G. Saraet al. "Pay-Level Satisfaction and Psychological Reward Satisfaction as Mediators of the Organizational JusticeTurnover Intention Relationship". International Studies of Management \& Organization, vol. 1, pp. 50, 2012.

[21] S. D. Janasz et. al. Interpersonal Skills in Organization. Boston: McGraw-Hill/Irwin, 2013. 